\title{
EVALUASI KUALITAS FISIK DAN KANDUNGAN DIGESTIBLE ENERGY DARI FERMENTASI KULIT UBI KAYU (Manihot utilissima) MENGGUNAKAN Aspergillus oryzae
}

\author{
Evaluation of Physical Quality and Digestible Energy Content From \\ Fermentation of Cassava Peel (Manihot utilissima) Using Aspergillus oryzae
}

\author{
Anton Wahyono ${ }^{1)}$, Siti Chuzaemi ${ }^{2)}$ \\ 1) Mahasiswa Fakultas Peternakan, Universitas Brawijaya, Malang, Jawa Timur, Indonesia, 65145 \\ ${ }^{2)}$ Dosen Fakultas Peternakan, Universitas Brawijaya, Malang, Jawa Timur, Indonesia, 65145 \\ E-mail: antonwahyono2@gmail.com
}

\begin{abstract}
ABSTRAK
Riset dilaksanan untuk mengetahui tingkat penggunaan Aspergillus oryzae terhadap kualitas fisik dan kandungan digestible energy pada fermentasi kulit ubi kayu. Metode yang digunakan yaitu Rancangan Acak Lengkap (RAL) dengan 4 perlakuan dan 3 kali ulangan sehingga terdapat 12 unit yang kemudian diuji menggunakan Duncan Jarak Berganda. Perlakuan yang digunakan dalam penelitian antara lain P0 (kulit ubi kayu + Aspergillus oryzae 0\%), P1 (kulit ubi kayu + Aspergillus oryzae 1\%), P2 (kulit ubi kayu + Aspergillus oryzae 2\%), P3 (kulit ubi kayu + Aspergillus oryzae 3\%) yang semua perlakuan difermentasi selama 96 jam pada kondisi aerob. Parameter yang diamati adalah kualitas fisik serta kandungan Digestible Energi (DE) ubi kayu. Hasil analisa statistik tingkat penggunaan kapang yang berbeda memberikan pengaruh yang positif terhadap aroma dan warna. Tingkat penggunaan Aspergillus oryzae yang berbeda pada fermentasi kulit ubi kayu berpengaruh sangat nyata $(\mathrm{P}<0,01)$ terhadap kandungan DE. Maka, dapat disimpulkan bahwa terdapat pengaruh nyata dari tingkat penggunaan Aspergillus oryzae yang berbeda terhadap kualitas fisik dan kandungan energi hasil fermentasi kulit ubi kayu.
\end{abstract}

Kata kunci: Aspergillus oryzae, digestible energy, fermentasi, kualitas fisik, kulit singkong

How to Cite:

Wahyono, A., \& Chuzaemi, S. (2021). Evaluasi Kualitas Fisik dan Kandungan Digestible Energy Dari Fermentasi Kulit Ubi Kayu (manihot utilissima) Menggunakan Aspergillus oryzae. Jurnal Nutrisi Ternak Tropis 4 (2) 109-116
*Corresponding author:

Anton Wahyono

Email: antonwahyono2@gmail.com

Fakultas Peternakan, Universitas Brawijaya, Malang,

Jawa Timur, Indonesia, 65145 


\begin{abstract}
Research are subjected to investigated the used of Aspergillus oryzae on physical quality and digestible energy content of fermented cassava peel. The method used is Completely Randomized Design (CRD) with 4 treatments and 3 replications so that there are 12 units which are then tested using Multiple Range Duncan. The treatments used in this study were PO (cassava peel + Aspergillus oryzae 0\%), P1 (cassava peel + Aspergillus oryzae 1\%), P2 (cassava peel + Aspergillus oryzae 2\%), P3 (cassava peel + Aspergillus oryzae 3\%) which all treatments were fermented for 96 hours under aerobic conditions. The variables observed were physical quality (color, texture, and aroma) and the content of Digestible Energy (DE). The results showed that cassava peel fermentation using Aspergillus oryzae $2 \%$ with a fermentation time of 96 hours gave the best results on the physical quality of cassava peel fermentation. The results of statistical analysis showed that the level of use of different molds had a very significant effect $(P<0.01)$ on aroma, significantly different $(P<0.05)$ on color, and not significantly different $(P>0.05)$ on texture. The different level of Aspergillus oryzae in casava fermentation had a very significant effect $(P<0.01)$ on the DE content. Thus, it can be concluded that there is a significant effect of the level of use of different Aspergillus oryzae on the physical quality and energy content of fermented cassava peels.
\end{abstract}

Key words: Aspergillus oryzae, cassava peel, digestible energy, fermentation, physical quality

\section{PENDAHULUAN}

Pakan merupakan hal yang penting bagi usaha peternakan, mengingat proporsi biaya pakan sekitar $74,71 \%$ dari keseluruhan biaya tidak tetap dari suatu usaha peternakan (Huda et al., 2020). Dari tahun ke tahun populasi ternak di Indonesia mengalami peningkatan tapi tidak diimbangi oleh peningkatan ketersediaan pakan (Tangendjaja, 2007). Berdasarkan data dari Kementerian Pertanian, produksi ubi kayu di Indonesia pada tahun 2018 sejumlah 19,3 juta ton. Selama tahun 2018 dihasilkan 4,8 juta ton kulit ubi kayu apabila persentase kulit $25 \%$ pada ubi kayu (Akhadiarto, 2010b). Kulit ubi kayu mengandung nutrisi yang terdiri dari bahan organik 93,72\% dari BK, protein kasar $5,25 \%$ dari BK, dan kadar pati 75,53\% dari BK (Sandi, 2012), serta nilai DE sebesar 55,06\% (Mulyasari dkk, 2013).

Permasalahan utama dari limbah ubi kayu yang berupa kulit ini berada pada kandungan sianidanya. Perlu dilakukan perlakuan yang dapat menurunkan kandungan sianida. Antari dan Umiyasih (2009) menyatakan bahwa kandungan sianida dapat diturunkan dengan cara fisika, kimia, maupun biologi. Perlakuan fisika berupa pencacahan, perendaman maupun pemanasan. Perlakuan kimia dengan penambahan bahan-bahan kimia, sedangkan untuk perlakuan biologi dapat dilakukan dengan cara fermentasi (Sjofjan et al., 2019).

Pemeraman merupakan proses yang menggunakan mikroba sebagai inokulannya (Nastiti et al., 2013). Fermentasi dapat menghasilkan warna yang diinginkan dan menghilangkan aroma yang tidak diinginkan dari substrat (Mulia dkk, 2015). Inokulum yang digunakan pada penelitian ini adalah jamur Aspergillus oryzae. Aspergillus oryzae digunakan karena dapat menghasilkan enzim linamarase yang dapat mengurai asam sianida, sehingga diharapkan kandungan sianida dalam kulit ubi kayu dapat berkurang.

Khoir dkk (2013) menyatakan bahwa fermentasi limbah padat bioetanol mampu menurunkan kandungan sianida sebanyak 16 mg/kg. Stephanie dan Purwadaria (2013) melaporkan bahwa kapang memiliki DE sebesar 2,23 Mcal sedangkan kulit ubi kayu yang tidak difermentasi memiliki DE 1,79 Mcal. Onggok yang difermentasi menggunakan Aspergillus oryzae memiliki 
DE 2,48 Mcal, sedangkan onggok yang tidak difermentasi sebesar 2.42 Mkal.

\section{MATERI DAN METODE}

\section{Bahan Pembuatan Fermentasi Kulit Ubi Kayu (Manihot utilissima)}

1. Kulit ubi kayu (Manihot utilissima)

Limbah kulit ubi kayu yang didapat dari produsen keripik ubi kayu dari Kecamatan Turen, Malang.

Bahan Analisis Variabel

Formulir yang diisi oleh panelis untuk menilai produk fermentasi.

Alat

Peralatan yang digunakan dalam pembuatan fermentasi kulit ubi kayu terdiri dari: timbangan, sendok, dan plastik. Peralatan yang digunakan untuk analisis kualitas fermentasi yaitu:

1. Nampan yang digunakan sebagai wadag produk fermentasi.

2. Kamera untuk mendokumentasikan kegiatan penilaian.

Analisis proksimat menggunakan berbagai instrumen antara lain

1. Analisis bahan kering dan bahan organic
2. Timbangan analitik, cawan porselin, eksikator, oven $105 \mathrm{oC}$, penjepit, dan tanur 550-600oC.

3. Analisis protein kasar

4. Timbangan analitik, labu Kjeldahl, gelas ukur, destructor, dan alat distilasi.

5. Analisis serat kasar

6. Timbangan analitik, gelas beker, pemanas, cawan filtrasi, dan oven 105 oC.

7. Analisis lemak kasar

8. Timbangan analitik, kertas saring, selongsong, alat destilasi, oven $105 \mathrm{oC}$, dan eksikator.

\section{Metode Penelitian}

Metode yang digunakan dalam penelitian adalah percobaan laboratorium dengan Rancangan Acak Lengkap (RAL) dengan 4 perlakuan dan 3 ulangan setiap perlakuaannya sehingga diperoleh 12 unit percobaan. Penilaian kualitas fisik fermentasi dilakukan oleh 10 panelis yang terlatih dengan rentang skor 0-4. Kandungan digestible energy dihitung menggunakan persamaan (Hartadi dkk,1980; Sjofjan et al., 2020). Persamaan penghitungan kandungan digestible energy (DE) yaitu:

$$
\mathrm{DE}(\mathrm{Mcal} / \mathrm{kg})=\mathrm{TDN} \% \times 0,04409
$$

Perlakuan yang dilakukan dalam penelitian adalah:

$$
\begin{aligned}
& \mathrm{P} 0=\text { Kulit ubi kayu }+ \text { tanpa Aspergillus oryzae (fermentasi } 96 \text { jam) } \\
& \mathrm{P} 1=\text { Kulit ubi kayu }+ \text { Aspergillus oryzae } 1 \% \text { (fermentasi } 96 \text { jam) } \\
& \mathrm{P} 2=\text { Kulit ubi kayu }+ \text { Aspergillus oryzae } 2 \% \text { (fermentasi } 96 \text { jam) } \\
& \mathrm{P} 3=\text { Kulit ubi kayu }+ \text { Aspergillus oryzae } 3 \% \text { (fermentasi } 96 \text { jam) }
\end{aligned}
$$

\section{Prosedur Pembuatan Fermentasi Kulit} Ubi Kayu

1. Kulit ubi kayu dibersihkan dan dicuci kemudian dirajang 1-3 cm;

2. Diangin-anginkan hinga kadar air $65 \%$;

3. Kulit ubi kayu ditimbang $100 \mathrm{~g}$ dan ditambah Apergillus oryzae sesuai perlakuan;

4. Kulit ubi kayu dan Aspergillus oryzae dihomogenkan;

5. Wadah plastik (fermentor) dilubangi,

6. Diuji kualitas fisik oleh panelis; dan
7. Dikeringkan pada suhu $60^{\circ} \mathrm{C}$ dan digiling dengan ukuran $1 \mathrm{~mm}$ untuk dianalisa proksimat dan kandungan DE.

\section{Parameter}

Parameter yang diamati adalah kualitas fisik (warna, tekstur, aroma) dan kandungan energi (Digestible Energy).

\section{Analisis Data}

Data yang diperoleh kemudian di tabulasi dan dianalisa menggunakan analisis ragam (Anova) dengan bantuan perangkat lunak microsoft excel. 


\section{HASIL DAN PEMBAHASAN}

\section{Kualitas Fisik Fermentasi Kulit Ubi Kayu \\ Hasil analisis warna, aroma, dan tekstur fermentasi kulit ubi kayu ditampilkan pada tabel 1 . \\ Pengaruh Perlakuan Terhadap Warna Fermentasi Kulit Ubi Kayu}

Hasil analisa ragam dari pengamatan panelis menunjukkan bahwa perlakuan tingkat penggunaan Aspergillus oryzae yang berbeda pada fermentasi kulit ubi kayu memberikan pengaruh nyata $(\mathrm{P}<0,05)$ terhadap warna hasil fermentasi. Warna yang dominan pada hasil fermentasi yaitu warna cokelat kehijauan. Warna hasil ferementasi dari P2 yaitu cokelat dengan skor 3,10, P0 dan P1 berwarna cokelat kehijauan dengan skor 2,90 dan 2,93, serta P3 berwarna cokelat kehijauan dengan skor 2,53.

Perubahan warna fermentasi disebabkan adanya proses fermentasi pada keadaan aerob dan selama persediaan gula masih tersedia (Kurnianingtyas dkk, 2012). Skor pengamatan tertinggi yaitu pada P2 dengan skor 3,10 yang berwarna cokelat. Skor tersebut menunjukkan perubahan warna tidak terlalu jauh beda dengan warna kulit ubi kayu sebelum difermentasi. Warna yang dikehendaki dari hasil fermentasi adalah warna cokelat terang atau skor 4,00.

Tabel 1. Kualitas fisik hasil fermentasi kulit ubi kayu dengan tingkat penggunaan Aspergillus oryzae yang berbeda

\begin{tabular}{cccc}
\hline Perlakuan & \multicolumn{3}{c}{ Variabel } \\
\cline { 2 - 4 } & Warna & Aroma & Tekstur \\
\hline P0 $(0 \%)$ & $2,90 \pm 0,99^{\mathrm{b}}$ & $2,10 \pm 0,30^{\mathrm{a}}$ & $2,67 \pm 0,71$ \\
P1 $(1 \%)$ & $2,93 \pm 0,78^{\mathrm{b}}$ & $2,20 \pm 0,84^{\mathrm{a}}$ & $2,83 \pm 0,70$ \\
P2 $(2 \%)$ & $3,10 \pm 0,76^{\mathrm{c}}$ & $2,53 \pm 0,73^{\mathrm{b}}$ & $2,87 \pm 0,51$ \\
P3 $(3 \%)$ & $2,53 \pm 1,01^{\mathrm{a}}$ & $2,53 \pm 0,82^{\mathrm{b}}$ & $2,90 \pm 0,66$ \\
\hline
\end{tabular}

Keterangan: ${ }^{\text {a,b,c. }}$ superskrip yang berbeda

pada kolom warna menunjukkan perbedaan yang nyata $(\mathrm{P}<0,05)$.

superskrip yang berbeda pada kolom aroma menunjukkan perbedaan yang sangat nyata $(\mathrm{P}<0,01)$.

\section{Pengaruh Perlakuan Terhadap Aroma Fermentasi Kulit Ubi Kayu}

Berdasarkan hasil Uji Jarak

Berganda Duncan, diketahui bahwa perlakuan dengan nilai terendah adalah $\mathrm{P} 0$ dan nilai tertinggi adalah P3. Perlakuan kontrol $(\mathrm{P} 0)$ berbeda sangat nyata $(\mathrm{P}<0,01)$ dibanding dengan $\mathrm{P} 2$ dan $\mathrm{P} 3$, tetapi tidak berbeda nyata dibanding P1. Penelitian yang dilaporkan oleh Mirnawati (2007) bahwa fermentasi dapat menghasilkan aroma yang lebih disukai oleh ternak. Hasil perlakuan kontrol (P0) dan P1 memiliki aroma apek dengan skor 2,10 dan 2,20. Hasil P2 dan P3 memiliki aroma yang lebih asam dibanding P0 dan P1. Aroma hasil fermentasi yang dikehendaki yaitu aroma manis atau skor 4,00 sesuai dengan format penilaian panelis. Aroma fermentasi yang baik menurut Lamid dkk (2012) adalah aroma yang harum seperti roti, tetapi tidak menyengat dan berbau busuk.

Munculnya aroma asam khas fermentasi disebabkan karena adanya perombakan ikatan lignoselulosa dan lignohemiselulosa oleh inokulum. Pengaruh yang sangat nyata juga terlihat pada fermentasi eceng gondok menggunakan Effective microorganism (EM4) (Irawati dkk, 2019). Yuliana dan Chuzaemi (2019) juga melaporkan bahwa fermentasi ampas putak menggunakan Aspergillus oryzae menghasilkan aroma yang berbeda sangat nyata. Hasil fermentasi P0 (0 jam), P3 (72 jam), dan P4 (96 jam) beraroma apek, sedangkan P1 (24 jam) dan P2 (48 jam) beraroma asam. Hasil berbeda dilaporkan oleh Marhamah dkk (2019), bahwa 
penggunaan starbio $0,5 \%$ sebagai starter fermentasi konsentrat dengan formulasi yang berbeda tidak menyebabkan perbedaan yang nyata. Semua perlakuan beraroma asam.

\section{Pengaruh Perlakuan Terhadap Tekstur Fermentasi Kulit Ubi Kayu}

Perlakuan tingkat penggunaan Aspergillus oryzae pada fermentasi kulit ubi kayu tidak memberikan pengaruh yang nyata $(\mathrm{P}>0,05)$. Hal ini dapat dilihat pada tabel 1 tidak terdapat superskrip. Perlakuan yang memiliki skor tertinggi yaitu P3 dengan skor 2,90, sedangkan yang memperoleh skor terendah yaitu P0 dengan skor 2,67. Seluruh perlakuan menghasilkan fermentasi yang bertekstur kenyal. Tekstur yang diharapkan pada hasil fermentasi yaitu tekstur lunak atau skor 4,00 pada format penilaian panelis.

Hal yang sama dilaporkan oleh Allaily dkk (2017) dan Irawati dkk (2019) bahwa perlakuan lama pemeraman yang berbeda pada ransum itik belum mampu memberikan yang berbeda nyata terhadap tekstur ransum terfermentasi. Hasil penelitian yang berbeda dilaporkan oleh Yuliana dan Chuzaemi (2019) fermentasi mengalami perubahan tekstur yang signifikan diduga sebelum diinokulasi kapang, bahan pakan telah mengalami perlakuan pengukusan. Kurniawan dkk. (2016) melaporkan bahwa perlakuan pengukusan ampas kelapa mengalami perubahan tekstur menjadi lembut, hal ini disebabkan pengukusan menyebabkan pelebaran pori-pori ampas kelapa. Kadar air erat kaitannya dengan aktivitas metabolism kapang yang diinokulasikan pada bahan pakan (Sukma dkk., 2010). Kualitas fermentasi yang baik menurut Larangahen dkk (2017) yaitu teksturnya tidak lembek, tidak berair, dan tidak menggumpal.

\section{Pengaruh Perlakuan Terhadap} Kandungan Digestible Energy

Kandungan digestible energy dari suatu bahan pakan dapat dihitung berdasarkan hasil analisa proksimat dan nilai TDN. Hasil analisa proksimat fermentasi kulit ubi kayu menggunakan Aspergillus oryzae disajikan pada tabel 2 dan nilai TDN disajikan pada tabel 3.

Tingkat penggunaan Aspergillus oryzae yang berbeda pada fermentasi kulit ubi kayu memberikan pengaruh yang sangat nyata $(\mathrm{P}<0,01)$ pada nilai digestible energy. Nilai digestible energy pada substrat hasil fermentasi tersaji pada tabel 4 .

Tabel 2. Hasil analisa proksimat fermentasi kulit ubi kayu

\begin{tabular}{ccccccc}
\hline Perlakuan & BK & BO* & PK* $^{*}$ & LK $^{*}$ & SK* & BETN* \\
\hline P0 & 19,70 & 93,10 & 7,15 & 2,17 & 25,65 & 58,13 \\
P1 & 19,59 & 93,07 & 5,47 & 2,40 & 23,78 & 61,41 \\
P2 & 21,34 & 93,08 & 4,07 & 2,54 & 21,63 & 64,83 \\
P3 & 20,28 & 93,39 & 3,95 & 1,81 & 21,65 & 65,97
\end{tabular}

Keterangan: * Berdasarkan 100\% Bahan Kering

Hasil Analisa Laboratorium Nutrisi dan Makanan Ternak Fakultas Peternakan Universitas Brawijaya, 2020

Tabel 3. Nilai Total Digestible Nutrient (TDN) fermentasi kulit ubi kayu

\begin{tabular}{cc}
\hline Perlakuan & Nilai TDN $(\%)$ \\
\hline P0 & $65,58 \pm 0,83$ \\
P1 & $69,94 \pm 1,06$ \\
P2 & $71,51 \pm 0,37$ \\
P3 & $72,92 \pm 0,51$ \\
\hline
\end{tabular}

Sumber: Putri (2020) 
Tabel 4. Nilai Digestible Energy (DE) hasil fermentasi kulit ubi kayu dengan tingkatan penggunaan Aspergillus oryzae yang berbeda

\begin{tabular}{cc}
\hline Perlakuan & DE $(\mathrm{Mcal} / \mathrm{kg})$ \\
\hline P0 & $3,02 \pm 0,04^{\mathrm{a}}$ \\
P1 & $3,08 \pm 0,05^{\mathrm{a}}$ \\
P2 & $3,15 \pm 0,02^{\mathrm{b}}$ \\
P3 & $3,22 \pm 0,02^{\mathrm{b}}$ \\
\hline
\end{tabular}

Keterangan: ${ }^{\mathrm{a}, \mathrm{b}}$ superskrip yang berbeda pada kolom yang sama menunjukkan perbedaan yang sangat nyata $(\mathrm{P}<0,01)$.

$* 1 \mathrm{Mcal}=1000 \mathrm{Kkal}$

Nilai DE tertinggi terdapat pada hasil fermentasi P3 dengan nilai 3,22 Mcal/kg. berdasarkan tabel 4 dapat diketahui bahwa semakin banyak penambahan kapang atau inokulum pada substrat diikuti oleh tingginya nilai digestible energy. Hal ini juga terjadi pada laporan penelitian Fitrihidajati dkk (2015) bahwa kandungan energi eceng gondok yang difermentasi menggunakan ragi tempe sebanyak $24,5 \%$ mengandung energi sebesar $1000 \mathrm{Kkal} / \mathrm{kg}$. Perbandingan yang cukup besar pada kandungan energi eceng gondok yang digunakan sebagai kontrol (ragi tempe 0\%) mengandung energi sebesar 800 $\mathrm{Kkal} / \mathrm{kg}$.Meskipun ternak ruminansia dapat mencerna serat kasar menjadi energi, tetapi hanya sebagian serat kasar yang dapat dicerna. Adanya perlakuan fermentasi pada bahan pakan ini dapat meningkatkan daya cerna zat bahan pakan khususnya energi (Stephanie dan Purwadaria, 2013). Wizna dkk (2014) menyatakan bahwa adanya inokulum yang tumbuh baik pada substrat dapat menghasilkan enzim selulase dengan jumlah yang banyak. Enzim selulase yang dihasilkan dapat merombak serat kasar dan karbohidrat menjadi glukosa yang akhirnya meningkatkan nilai DE yang dimanfaatkan oleh ternak.

Kebutuhan digestible energy domba pada fase fisiologis berbeda - beda. Kebutuhan digestible energy domba untuk hidup pokok sebesar 0,65 Mcal/ekor/hari, sedangkan kebutuhan DE untuk pertambahan bobot hidup harian ( $\mathrm{g} /$ hari) sebesar 3,65 Mcal/ekor/hari (Mathius et al, 1996). Kulit ubi kayu terfermentasi dengan jumlah $0,21 \mathrm{~kg}$ sudah mengandung DE sebesar 0,65 Mcal dengan kulit ubi kayu yang mengandung 3,15 Mcal $/ \mathrm{kg}$. Kebutuhan DE untuk memperoleh pertambahan bobot harian (g/hari) diperlukan kulit ubi kayu P2 sejumlah 1,16 kg. Kulit ubi kayu P2 1,16 kg mengandung DE sebesar 3,65 Mcal.

\section{KESIMPULAN}

Fermentasi ubi kayu memiliki pengaruh positif terhadap kualitas fisik dan kandungan digestible energy (DE) dengan penggunaan Aspergillus oryzae sebanyak $2 \%$ memberikan hasil fermentasi terbaik yaitu berwarna cokelat terang, bertekstur sedikit kenyal, dan beraroma sedikit asam dengan kandungan DE 3,153 Mcal/kg.

\section{DAFTAR PUSTAKA}

Abdelhadi, L. O., Santini, F. J., \& Gagliostro, G. A. (2005). Corn silage or high moisture corn supplements for beef heifers grazing temperate pastures: effects on performance, ruminal fermentation and in situ pasture digestion. Animal Feed Science and Technology, 118(1-2), 63-78. https://doi.org/10.1016/j.anife edsci.2004.09.007

Akhadiarto, S. (2016). Pengaruh pemanfaatan limbah kulit singkong dalam pembuatan pelet ransum unggas. Jurnal Teknologi Lingkungan, 11(1), 127-138. https:// doi.org/10.29122/jtl.v11i1.1230

Allaily, A., Miswar, M., Rianah, S., Usman, Y., Zulfan, Z., \& Yaman, M. (2017). Potensi pakan fermentasi anaerob 
menggunakan bahan pakan lokal untuk ternak itik. Teknologi Peternakan Dan Veteriner Mendukung Diversifikasi Sumber Protein Asal Ternak, 428-435. https://doi.org/10.14334/Pros.Semnas .TPV-2017-p.430-437

Antari, R., \& Umiyasih, U. (2009). Pemanfaatan tanaman ubi kayu dan limbahnya secara optimal sebagai pakan ruminansia. Wartazoa, 19(4), 191-200.

Fitrihidajati, H., Ratnasari, E., Isnawati, \& Soeparno, G. (2015). Kualitas hasil fermentasi pada pembuatan pakan ternak ruminansia berbahan baku eceng gondok (Eichornia crassipes). Biosaintifika: Journal of Biology \& Biology Education, 7(1), 61-67. https://doi.org/10.15294/biosaintifika. v7i1.3540

Hartadi, H., Reksohadiprodjo, S., Lebdosukojo, S., \& Tillman, A. D. (1980). Tabel-tabel Komposisi Bahan Makanan Ternak Untuk Indonesia. International Feeds Institute.

Huda, A. N., Ndaru, P. H., Ridhowi, A., Nuningtyas, Y. F., Putritamara, J. A., \& Soetanto, H. (2020). Economic value of dwarf elephant grass and dried distiller grain with soluble as feed of smallholder dairy farm in Tulungrejo Village, Ngantang District, Malang Regency. IOP Conference Series: Earth and Environmental Science, 478(1), 012056. https://doi.org/10.1088/17551315/478/1/012056

Irawati, E., Purnamasari, E., \& Arsyad, F. (2019). Kualitas fisik dan nutrisi eceng gondok (Eichornia crassipes) dengan lama fermentasi yang berbeda. Jurnal Peternakan, 16(1), 18-24. https: //doi.org/10.24014/jupet.v16i1.3679

Khoir, A., Suryani, Y., \& Sa'adah, S. (2013). Fermentasi limbah padat pengolahan bioetanol singkong (manihot esculenta) oleh aspergillus niger terhadap perubahan kandungan kualitas nutrisi. Jurnal Jurusan
Biologi Fakultas Sains Dan Teknologi, 7(2), 203-215.

Kurnianingtyas, I. B., Pandansari, P. R., Astuti, I., Widyawati, S. D., \& Suprayogi, W. P. S. (2012). Pengaruh macam akselerator terhadap kualitas fisik, kimiawi, dan biologis silase rumput kolonjo. Tropical Animal Husbandry, 1(1), 7-14.

Kurniawan, H. (2016). Kualitas nutrisi ampas kelapa (Cocos nucifera L.) fermentasi menggunakan Aspergillus niger. Buletin Peternakan, 40(1), 2633. https://doi.org/10.21059/buletin peternak.v40i1.9822

Lamid, M., Ismudiono, S, K., Chusniati, S., Hidayatik, N., \& EVF, V. (2012). Karakteristik silase pucuk tebu (saccharum officinarum, linn) dengan penambahan lactobacillus plantarum. Agroveteriner, 1(1), 5-10.

Larangahen, A., Bagau, B., Imbar, M. R., \& Liwe, H. (2016). Pengaruh penambahan molases terhadap kualitas fisik dan kimia silase kulit pisang sepatu (Mussa paradisiaca formatypica). ZOOTEC, 37(1), 156166. https://doi.org/10.35792/zot.37. 1.2017.14419

Marhamah, S. U., Akbarillah, T., \& Hidayat, H. (2019). Kualitas nutrisi pakan konsentrat fermentasi berbasis bahan limbah ampas tahu dan ampas kelapa dengan komposisi yang berbeda serta tingkat akseptabilitas pada ternak kambing. Jurnal Sain Peternakan Indonesia, 14(2), 145-153. https://doi. org/10.31186/jspi.id.14.2.145-153

Mathius, I. M., Martawidjaja, M., Wilson, A., \& Manurung, T. (1996). Studi strategi kebutuhan energi-protein untuk domba lokal: I. fase pertumbuhan. Jurnal Ilmu Ternak Dan Veteriner, 2(2), 84-91.

Mirnawati, M. (2007). Peningkatan kualitas bungkil inti sawit dengan fermentasi terhadap aktivitas enzim dan kandungan zat makanan. Jurnal Peternakan Indonesia (Indonesian Journal of Animal Science), 12(2), 
105-111. https://doi.org/10.25077/jpi. 12.2.105-111.2007

Mulia, D. S., Yulyanti, E., Maryanto, H., \& Purbamartono, C. (2015). Peningkatan kualitas ampas tahu sebagai bahan baku pakan ikan dengan fermentasi Rhizopus oligosporus. Sainteks, 12(1), 10-20. https://doi.org/10.30595/SAIN TEKS.V12I1.83

Mulyasari, Kurniawati, F., \& Setiawati, M. (2015). Digestibility of pre-treated cassava peel as feed ingredient for Nile tilapia. Jurnal Akuakultur Indonesia, 12(2), 178-185. https:// doi.org/10.19027/jai.12.178-185

Nastiti, U. N., Lastuti, N. D. R., \& Nurhajati, T. (2013). The decreasing of crude fiber and the increasing of crude protein content of pineapple peel (Ananas comosus L. Merr) which fermented by cellulolytic bacteria (Actinobacillus sp. ML-08). AGROVETERINER, 1(2), 46-54.

Putri, G. R. A. (2020). Pengaruh Tingkat Penggunaan Aspergillus oryzae pada Fermentasi Kulit Ubi Kayu (Manihot utilissima) Terhadap Kandungan $H C N$, TDN, dan $p H$. Universitas Brawijaya.

Sandi, S. (2012). Nilai nutrisi kulit singkong yang mendapat perlakuan bahan pengawet selama penyimpanan. Jurnal Penelitian Sains (JPS), 15(2), 88-92.

Sjofjan O., Adli D.N., Hanani P.K., \& Sulistiyaningrum D. (2020). The utilization of bay leaf (SyzygiumpolyanthumWalp) flour in feed on carcass quality, microflora instestine of broiler. International Journal of Engineering Technologies and Management Research, 6(11), 19. https://doi.org/10.29121/ijetmr.v6.i 11.2019 .458
Sjofjan, O., Nur Adli, D., Djunaidi, I., \& Kuncoro, K. (2020). Utilization of biogas liquid waste for starter in the fermentation of rice husk as a potential feed for poultry. Animal Production, 22(1), 24-30. https://doi.org/10.20884 /1.jap.2020.22.1.38

Steel, R. G., \& Torrie, J. H. (1993). Prinsip dan Prosedur Statistika Suatu Pendekatan Biometrik (M. Syah (ed.)). Gramedia Pustaka Utama.

Stephanie, \& Purwadaria. (2013). Fermentasi substrat padat kulit singkong sebagai bahan pakan ternak unggas. Wartazoa, 23(1), 15-22.

Sukma, L. N., Zackiyah, \& Gumilar, G. G. (2010). Pengkayaan asam lemak tak jenuh pada bekatul dengan cara fermentasi padat menggunakan aspergillus terreus. Jurnal Sains Dan Teknologi Kimia, 1(1), 66-72.

Tangendjaja, B. (2007). Inovasi teknologi pakan menuju kemandirian usaha ternak unggas. Wartazoa, 17(1), 12-20.

Wizna, W., Muis, H., \& Deswan, A. (2014). Pengaruh dosis inokulum dan lama fermentasi campuran dedak padi dan darah dengan bacillus amyloliquefaciens terhadap kandungan serat kasar, kecernaan serat kasar dan energi metabolisme. Jurnal Peternakan Indonesia (Indonesian Journal of Animal Science), 16(2), 128-133. https://doi. org/10.25077/jpi.16.2.128-133.2014

Yuliana, A., \& Chuzaemi, S. (2019). Pengaruh lama fermentasi ampas putak (Corypha gebanga) terhadap kualitas fisik dan kualitas kimia menggunakan aspergillus oryzae. Jurnal Nutrisi Ternak Tropis, 2(1), 19-32. https://doi.org/10.21776/ub. jnt.2019.002.01.3 